\title{
ROSTICIDADE TELEVISIVA
}

\author{
Television Facity \\ Rostricidad Televisiva
}

\author{
Marcelo Salcedo Gomes \\ Doutor em Ciências da Comunicação - UNISINOS \\ salcedogomes@gmail.com
}

\section{Resumo}

Tensiona-se, neste trabalho, a natureza do devir-rosto em processos midiáticos, especificamente em panoramas televisivos. A partir da criação do conceito de rosticidade, propõe-se sua discussão como uma qualidade comunicacional virtual que se atualiza em tecnoimagens de rosto ou de algo que toma o lugar de rosto para se fazer reconhecer como autêntico. Em busca da rosticidade televisiva, foram dissecadas imagens dos programas telejornalísticos Estúdio i e SBT Brasil, através da metodologia das molduras de Kilpp, procurando analisar os elementos técnicos e estéticos que trabalham em favor de uma "máquina abstrata" rostizante, postulada por Deleuze e Guattari. A dissecação, enquanto técnica de análise, aponta que os sentidos identitários enunciados pela produção de certas imagens televisivas se fazem rosto na medida em que evocam padrões de um imaginário tecnocultural assimetricamente compartilhado entre produtores e espectadores.

Palavras-chave: Rosticidade. Televisualidade. Tecnocultura.

\begin{abstract}
This paper aims at considering the nature of Deleuzian becoming-face in media processes, specifically in television panoramas. From the creation of the notion of facity, it is discussed as a virtual communication quality that is updated in technoimages of faces or of something that takes the place of a face in order to be recognized as authentic. By seeking the facity in television, we proceed to the dissection of TV news images of the journalistic programs Estúdio $i$ and SBT Brasil, through the methodology of frames proposed by Kilpp, attempting to discern technical and aesthetic elements that work in favor of the facefying "abstract machine" postulated by Deleuze and Guattari. The dissection points out that the identity meanings set out by the production of certain television images are turned into faces as evocative patterns of an asymmetrically shared technocultural imaginary.
\end{abstract}

Key words: Facity. Televisuality. Technoculture.

\section{Resumen}

Se reflexiona aquí sobre la naturaleza de el devenir-rostro en los procesos de comunicación, específicamente en panoramas de televisión. Desde la invención del concepto de rostricidad, se propone la discusión de una calidad comunicación virtual que se actualiza en tecnoimágenes de rostro o algo que toma el lugar de rostro a ser reconocido como auténtico. Se procede a la disección de imágenes de los noticiarios de TV Estúdio I y SBT Brasil, a través de la 
metodología de los marcos de Kilpp, buscando discernir elementos técnicos y estéticos que trabajan en favor de la rostizante "máquina abstracta" postulada por Deleuze y Guattari. La disección señala que los significados de identidad enunciados por la producción de determinadas imágenes de televisión se hacen rostro en la medida en que evocan patrones de una imaginaria tecnocultural asimétricamente compartida.

Palabras clave: Rostricidad. Televisualidad. Tecnocultura.

\section{INTRODUÇÃO}

Este trabalho versa sobre a importância e a significação do rosto nos processos midiáticos contemporâneos, em especial na televisão, e suas reverberações na chamada tecnocultura ${ }^{1}$. A fisionomia, ao longo da história, tem sido objeto de inúmeros pensadores que se debruçam sobre o caráter do rosto como um tipo especial de imagem que norteia experiências sensoriais e memoriais, perceptos e afectos. No que concerne ao campo da comunicação, tornaram-se relevantes estudos sobre o rosto na e da fotografia, como Benjamin (1989), Picado (2009) e Marques e Biondi (2016); no e do cinema, dos quais destaca-se Balázs (2003) e Deleuze (2009); e na e da televisão, como em Canevacci (1998), Frosh (2009) e Lage (2017).

Não seria exagero, portanto, pensar que o rosto ganhou um lugar privilegiado na ecologia da cultura visual como imagem (nos termos de Bergson), assim como observou Lage (2017, p. 160) a respeito do rosto como "tópica visual proeminente" nas investigações sobre fotografia, cinema e televisão.

A partir da discussão, na próxima seção do texto, do conceito de rosticidade, busca-se identificar, em construtos televisivos, as marcas de uma qualidade comunicacional virtual que se atualiza em tecnoimagens de rosto, ou de algo que toma o lugar de rosto, para se fazer reconhecer como singularidade, dentro de um quadro mobilizado pelo imaginário tecnocultural. Neste sentido, o presente artigo traduz uma parte do trajeto da pesquisa de doutorado que culminou na tese A rosticidade da tecnocultura na galáxia National Geographic (GOMES, 2017).

\footnotetext{
${ }^{1}$ Assume-se, neste artigo, que a tecnocultura é um devir cultural em que o avanço da técnica faz surgir outros modos de ser e agir no mundo, engendrando uma ambiência que imprescinde dos meios técnicos para existir. Um dos seus aspectos centrais parece ser uma forma de comunicação que tensiona as noções de espaço e de tempo, vetorizada pelas tecnologias convertidas em meios em uma sociedade globalmente midiatizada e conectada por aparelhos.
} 
O conceito de imaginário (CASTORIADIS, 1982; APPADURAI; TAYLOR, 2004) relaciona-se à forma como um determinado grupo ou sociedade imagina sua própria existência e a refere com o mundo em que vive. Sua presença é percebida através de um conjunto heterogêneo e essencialmente indeterminado de marcas (imagens, histórias, mitos, formas...) manifestadas na vida cotidiana, nas artes, nas mídias... Sendo assim, é o imaginário que legitima as práticas sociais, segundo Kilpp (2003), enquanto mediações.

O imaginário televisivo seria aquele pelo qual a televisão imagina o mundo e é imaginada por ele, cujas marcas são percebidas nas materialidades das imagens na tela e cujos significados se tornam compreensíveis porque são compartilhados coletivamente, mesmo que de forma parcial. É preciso salientar que a percepção ocorre em uma consciência individual, a partir de uma moldura-corpo dotada de repertório cultural singular. A comunicação de sentidos se dá, justamente, neste complexo compartilhamento de imaginários.

Flichy (2001) defende a emergência de um "imaginário tecnológico" , o qual tem um preponderante papel na construção de um mundo comum, em que os atores dos múltiplos setores sociais articulam o processo de modulação tecnológica. Considerando essas duas noções e atrelando-as ao conceito de tecnocultura, postula-se aqui um "imaginário tecnocultural”, visto ser a tecnocultura, simultaneamente, matéria-prima, processo e produto dos sentidos identitários coletivos na contemporaneidade.

Mas de que modo pode-se estudar este imaginário comunicacionalmente? Através dos indícios enunciativos materializados, no caso do mundo televisivo, nas imagens técnicas vistas na tela, as quais podem ser acessadas por espectadores-analistas. Na busca por tais indícios, empreende-se a dissecação (KILPP, 2003) de um conjunto de imagens dos programas telejornalísticos Estúdio i e SBT Brasil, através da metodologia das molduras proposta por Kilpp (2003 e 2010), apresentada na seção 4. Para a autora, aquilo que trama o "propriamente televisivo" pode ser entendido a partir de três eixos conceituais: 1) o eixo das ethicidades, enquanto subjetividades virtuais; 2) o eixo das molduras (unidades discretas que delimitam um território passível de significação), moldurações (processualidades produzidas no interior das molduras a fim de lhes oferecer sentido) e emolduramentos (sentidos ofertados pela produção) e; 3) o eixo dos imaginários, os quais permitem a comunicação desses sentidos, permeados pela moldura-corpo do espectador.

Antes disso, porém, na seção 3, a fim de entender a trajetória conceitual dos estudos que trataram o rosto como imagem de tipo singular, são discutidos fragmentos das acepções de Baláz (2003) sobre a mudança percentual ocasionada pela invenção do close up no cinema, de 
Canevacci (1998) sobre a preponderância do primeiro plano televisivo na constituição de uma fixidez da face na tela, reencarnando no ecrâ os elementos mágicos e sacrais arcaicos da máscara, dentre outros. Imprescindível para esta discussão é também a noção de uma "máquina abstrata de rostidade" (DELEUZE \& GUATTARI, 1996) que põe em funcionamento um duplo mecanismo de significância e subjetivação que a todos esquadrinha na ânsia de produzir rostosmodelos.

É necessário, desde já, esclarecer alguns termos para evitar possíveis ambiguidades: 1) quando se fala, neste texto, do verbete "rosto" refere-se não só à face humana mas, em sentido amplo, também à fisionomia imaginada a outras parte do corpo, outros organismos, paisagens, instituições e as coisas em geral, no processo de "rostificação" de algo, a qual diz respeito a dar aparência de rosto ao que não é rosto; 2) quando é usado o termo "rostidade", refere-se à tradução brasileira do conceito desenvolvido por Deleuze e Guattari (1996), que remete à produção de uma "máquina abstrata" que a tudo impõe um padrão de rosto ideal; 3) e, finalmente, quando se usa a palavra "rosticidade" aponta-se para a construção do conceito de um devir-rosto que se atualiza em rostos da tecnocultura visual e audiovisual (GOMES, 2017).

\section{A ROSTICIDADE COMO QUALIDADE COMUNICACIONAL}

A intenção de estudar o papel do rosto em processos midiáticos, surgiu de um questionamento sobre sua natureza comunicacional e imagética (como devir-rosto, como qualidade de rosto) que dura (BERGSON, 2006) nas atualizações de rostos em imagens técnicas nas diferentes mídias: fotografia, cinema, vídeo, televisão, games, internet etc.

A ideia de buscar esta qualidade nos diversos meios é inspirada na proposta de estudo das audiovisualidades, que, segundo Kilpp (2011, p. 225), é "uma perspectiva de pesquisa desconstrutiva, que se liquefaz - ou coloca em movimento - as antes sólidas fronteiras da pesquisa das imagens de um dispositivo e as das de outro, pesquisa essa que, assim, hospeda em seu corpus os devires minoritários das de cada um”. As audiovisualidades estariam relacionadas a uma virtualidade imagética que se atualiza nos diversos dispositivos do olhar, propondo a invenção de um objeto de pesquisa que não se reduziria a uma mídia específica, mas que se manifesta de modos específicos em cada uma delas.

A partir da discussão de um devir-rosto, de uma qualidade comunicacional virtual que se atualiza em imagens de rostos - ou de algo que ocupa o lugar do rosto -, que dura no tempo e conserva na memória toda potencialidade daquilo que se quer reconhecer como único, 
assume-se o conceito de rosticidade como hipótese heurística para daí formarem-se outras constelações de sentido.

Nesta perspectiva, concebe-se o rosto nas imagens não apenas como uma imagem documental que registra a face humana (importante para a antropologia visual e para os estudos sobre alteridade), mas também como metáfora fisionômica imaginada a outras partes do corpo, outros organismos, formas abstratas, paisagens, personagens, narrativas, instituições e às coisas em geral que só ganham vida [e sentido] quando se lhes atribui um rosto. A preponderância do rosto na comunicação é apropriada inclusive para confeccionar objetos que lembram o rosto, ainda que não sejam rostos: o design do produtos, as embalagens, a "cara" das coisas..., enfim, aquilo que se quer representar como singular e/ou autoral. Poder-se-ia dizer que até mesmo imagens aparentemente livres das amarras do referente também tornam-se imagem-rosto quando trabalham as formas, as texturas, as cores, a luz...

A representação de uma fisionômica através do rosto/imagem talvez seja a forma mais expressiva de que as mídias podem dispor para estabelecer a afecção, que se engendra, pela percepção, nos sentidos, e constrói a inteligibilidade no próprio fluxo comunicacional. Como já dissera Benjamin (1989), a renúncia ao homem é a exigência mais difícil de se fazer no que concerne às tecnoimagens. Se Benjamin percebera em seu tempo as peculiaridades deste tipo especial de imagem, o que se pode dizer sobre a proliferação delas no audiovisual contemporâneo? É neste sentido que se propõe compreender essa fisionômica dos rostos nas imagens tecnoculturais como potencializadoras, não só de discursos midiáticos, mas também de uma virtualidade, de uma qualidade que está para além da percepção da imagem do que é preciso para agir, mobilizada através da expressão de um rosto. Uma sensação de atração e distanciamento simultâneos que faz da face seu “objeto de culto", tomado aqui não como crença religiosa, mas como força do desejo produzido por um trabalho da memória involuntária que se nutre das imagens (em sentido amplo) em devir que compõem o imaginário tecnocultural de uma época.

Um virtual se atualizando nas práticas imagéticas de rostos na tecnocultura visual e audiovisual que leva a refletir sobre os sentidos produzidos nesta experiência do rosto-memória. Este rosto que se atualiza como close, como primeiro plano, como visus (CANEVACCI, 1998, p. 69), como máscara primitiva, como caveira, enfim, como as inúmeras figuras e formas de rosto que povoam a ecologia das imagens audiovisuais contemporâneas e até mesmo em objetos inanimados que não são rostos, mas que se atualizam como rosto nos planos detalhe do cinema e da televisão, no design dos objetos técnicos, nas obras de arte, nas paisagens, nos discursos. 
PROGRAMA DE PÓS-GRADUAÇÃO EM COMUNICAÇÃO DA UNIVERSIDADE FEDERAL DE SANTA MARIA

Sendo assim, a rosticidade não se restringiria como uma tendência virtual às imagens de rosto, mas é um conceito de imagem síntese, de experiência aurática, de comunicação, de qualidade, de potência de rosto. A preponderância do rosto na comunicação visual é apropriada inclusive para confeccionar objetos que lembram o rosto, ainda que não sejam rostos. Trata-se de um design que dá forma de rosto ou aparência de rosto ao que não é rosto. A frente dos automóveis, a face dos produtos, a "cara" das coisas. Aquilo que se quer apresentar como autoral, que se quer reconhecer pelo seu rosto, pela sua "cara", sua individualidade, sua autenticidade.

Neste sentido, não se considera a rosticidade como fisicalidade, mas como uma qualidade da própria comunicação midiatizada. Rosticidade não seria a expressão do rosto em uma circunstância particular, mas a qualidade de uma comunicação mais genérica que desperta um conjunto de afectos e perceptos que têm a potencialidade de operar no arcabouço da memória e fazer-nos reconhecer certas imagens como marcas do imaginário tecnocultural.

\section{A ESCAVAÇÃO DAS IMAGENS-ROSTO TECNOCULTURAIS}

O interesse pelo significado do rosto não é recente, Baltrusaitis (1999) demonstra que a "fisiognomia" (que literalmente quer dizer interpretar o homem por sua aparência) já fora objeto de pesquisas e especulações de filósofos como Aristóteles e Descartes, de pintores como Leonardo Da Vinci e Michelângelo e de escritores como Zola, Goethe e Balzac. Eco (1989) nos diz que teóricos da arte, como Le Brun e Lavater, chegaram a defender, ressalvadas as diferenças entre as propostas, que era possível determinar cientificamente as paixões humanas através do estudo da geometria da face e que o caráter de um indivíduo poderia ser objetivamente representado nas obras.

Não obstante a fisiognomia ter se tornado inócua como instrumento objetivo de descrição e análise psicológica, ironicamente, a análise das qualidades universais do rosto nas imagens passou a oferecer complexas problematizações científicas, sociais, culturais e políticas.

Neste cenário, o estudo do significado do rosto expresso por imagens técnicas também tem importantes expoentes ao longo do tempo. É justamente em Benjamin (1984) que se encontra outro significado para a físiognomia, como a arte de escrever histórias através de imagens. $\mathrm{O}$ autor mostra uma estranha dimensão aurática presente nos rostos de pessoas 
anônimas nos primeiros daguerreótipos, que insistia em não se extinguir, apesar do "valor de culto" das obras estar em declínio à época.

Benjamin discute a noção de aura ao longo de sua obra com ao menos dois significados distintos. Um diz respeito ao declínio de uma atitude de contemplação burguesa diante da obra de arte, de um elitismo que celebra a arte pela arte, a "religião da arte" que entra em crise com a invenção das tecnologias de reprodução em favor de uma democratização da fruição estética. Outro significado para aura é encontrado nos estudos benjaminianos sobre Baudelaire, nos quais ele diz haver uma dimensão aurática não só relacionada à arte, mas também a um materialismo antropológico da experiência humana com o objeto visual, que pode ter o rosto como seu modelo mais significativo. Segundo esta concepção, quando se olha para um objeto, pode-se dar-lhe o poder de olhar de volta, o que se aplicaria também às materialidades fotográficas.

[...] renunciar ao homem é para o fotógrafo a mais irrealizável de todas as exigências. Quem não sabia disso, aprendeu com os melhores filmes russos que mesmo o ambiente e a paisagem só se revelam ao fotógrafo que sabe captá-los em sua manifestação anônima, num rosto humano (BENJAMIN, 1989, p. 102).

No cinema, Béla Baláz (2003) propôs que a expressão facial obtida com a invenção do close up no filme resgatou um tipo de comunicação ancestral que foge à racionalização da palavra impressa, assim como alguns pensamentos expressos na música são diferentes daqueles dos textos escritos. Não se trata das imagens visuais substituírem as palavras, mas de um meio de comunicação que torna visível o homem interior sem a necessidade da mediação verbal. Baláz chama a atenção para um processo de antropomorfização que faz das coisas rostos investidos de sentido humano. Note-se que o autor fala não só de rostos em primeiro plano, mas de objetos que, mostrados em close up, passam a constituirem-se como subjetivadores.

Quando o close-up retira o véu de nossa imperceptibilidade e insensibilidade com relação às pequenas coisas escondidas e nos exibe a face dos objetos, ele, ainda assim, nos mostra o homem, pois o que torna os objetos expressivos são as expressões humanas projetadas nesses objetos (BALÁZS, 2003, p. 92).

Partindo dos estudos do primeiro plano no cinema, Canevacci (1998) aponta o visus televisivo como uma espécie de máscara da modernidade, que exacerba a técnica de aumentar o rosto na tela por longos planos sequência que mantêm uma regularidade técnica e estética, universalizando os sentidos. Tais planos passariam a comunicar de modo transcultural toda sucessão de paixões reduzidas a um mesmo módulo elementar, daí o sucesso mundial das 
novelas brasileiras e das séries estadunidenses, segundo o autor, o que justificaria o lugar privilegiado do rosto na ecologia da cultura visual e nas investigações sobre as imagens midiáticas.

A televisão, sendo posterior ao cinema, conserva muitas de suas características, assim como o cinema conserva características da fotografia. Entretanto, as imagens de rosto fotográficas, televisivas e cinematográficas guardam diferenças significativas. A imagem fotográfica imobiliza um instante decisivo da fisionomia no tempo como só ela pode fazer, capaz de revelar características da imagem não captadas normalmente pelo olho humano, ao que Benjamin (1989) denomina de "inconsciente ótico". Já no cinema e na televisão, as imagens em movimento estabelecem outro regime de visualidade, que se estende no tempo. Contudo, na televisão, os headshots constituem uma transitoriedade (FROSH, 2009) ainda maior, pois, em geral, são utilizados com maior frequência e substituídos por outros headshots com mais rapidez. Ao assistir telenovelas, séries, reality shows e programas jornalísticos, percebe-se que as imagens de rosto ocupam boa parte da transmissão, sejam rostos de pessoas anônimas ou conhecidas, como de atores, apresentadores, jornalistas, políticos, etc.

Ainda, de acordo com Frosh (2009), o tamanho da imagem na televisão é menor do que no cinema e o espectador geralmente assiste TV a uma distância curta, frequentemente em um ambiente doméstico, o que propicia um tipo de envolvimento diferente entre o observador e que está sendo exibido. Se, no cinema os sinais faciais referem-se aos sentimentos dos personagens de acordo com a diegese do filme, na televisão, a produção da subjetividade nas fisionomias está voltada, em muitos casos (como nos programas jornalísticos e de auditório) para atingir diretamente o espectador. Os rostos da televisão causam a estranha sensação de estarem diante de nós, nos olhando nos olhos e nos interpelando através da câmera, sobretudo em programas ao vivo.

É por este motivo, segundo Frosh (2009), que a substituição de um âncora em um telejornal é uma das operações mais complicadas para uma emissora pois, a partir do momento em que a face de um apresentador se torna familiar (aqui no sentido mesmo de ser mais um rosto presente na sala da residência), passa a ser o próprio rosto do programa.

Deleuze e Guattari (1996), em Ano Zero - Rostidade 2 , postulam o rosto como dispositivo complexo de significância e subjetivação. Para eles, há uma "máquina abstrata de rostidade"

\footnotetext{
${ }^{2}$ É importante sublinhar que o conceito "rostidade" proposto por Deleuze e Guattari (1996) no capítulo Ano Zero - Rostidade da obra Mil Platôs: capitalismo e esquizofrenia Vol. 3, apesar de compor as discussões sobre, é totalmente distinto da ideia de "rosticidade" (GOMES, 2017).
} 
que a tudo impõe um rosto. Afirmam que o desenvolvimento desta máquina se acentuou justamente pelo desenvolvimento da civilização ocidental, cujo arquétipo é o homem branco cristão. No entanto, o modelo absoluto de rosto não é o rosto do homem branco, é o próprio homem branco europeu típico, "o rosto é o Cristo".

Tal máquina operaria pela montagem de um duplo sistema muro branco-buraco negro (grandes bochechas brancas e buraco negro dos olhos), metáfora que utilizaram para analisar dois mecanismos que atuam simultaneamente: enquanto o muro branco se apresenta como tela vazia pronta para receber os significados de uma razão compartilhada, o buraco negro se abre aos modos de subjetivação que abrigam toda sorte de paixões e afetos.

Esta maquinaria abstrata, ao estabelecer o rosto como sistema de referência dominante, esquadrinharia a tudo e a todos através de operações distintas: a das unidades, que constitui o rosto sempre a partir de contradições dicotômicas (homem x mulher, branco x negro, adulto $\mathrm{x}$ criança, rico x pobre, etc.) e a das escolhas, que são operações subjetivas de seleção e julgamento, que aceitam ou rejeitam o rosto conforme o grau de adequação social.

Todo significado deve passar pela máquina, nada fica de fora, os inadequados são aniquilados ou expulsos pelo rosto despótico da significância e pelo rosto autoritário da subjetivação. Segundo Deleuze e Guattari (1996, p. 46):

É preciso que o sistema buraco negro-muro branco quadricule todo o espaço, delineie suas arborescências ou suas dicotomias, para que a significância e a subjetividade possam apenas tornar concebível a possibilidade de suas operações.

Considerando a hipótese de que a máquina abstrata da rostidade se beneficiaria da potência dos meios de comunicação na constituição política de rostos e na manutenção de modelos homológicos, seria possível ver nas molduras e moldurações praticadas por um determinado dispositivo midiático as engrenagens da significância buscando enquadrar programas de televisão, filmes, capas de revista, jogos de vídeo game..., em sistemas binários de clichês bem definidos e subjetivadores que furam o buraco negro procurando estabelecer somente sentidos que se conformam ao padrão considerado adequado para comunicar.

No entanto, se, nos outros domínios, o homem só terá uma possibilidade de vida se buscar escapar do rosto e desarmar a máquina, isto é, viver sem rosto para ter liberdade, como propõem Deleuze e Guattari (1996), no mundo midiático, esta lógica parece se inverter: não ter rosto talvez signifique a "página em branco", o "filme queimado".

\section{TRAÇOS TELEVISUAIS DE ROSTICIDADE}


No que concerne à noção de rosticidade, pode-se considerar as proposições de Deleuze e Guattari (1996) e sugerir que opera, também na televisão, uma "máquina abstrata" que se manifesta através das moldurações praticadas dentro de territórios de significação bem delimitados. Neste sentido, a imagem televisiva funciona como o fundo no qual são inscritas as demais molduras. Os rostos concretos, nos dizem Deleuze e Guattari (1996), "nascem de uma máquina abstrata de rostidade" constituída de um sistema muro branco-buraco negro. Muro branco como superfície, tela na qual se inscreveriam os significantes e buraco negro como cavidade na qual escoa toda subjetividade.

No entanto, outras combinações nas quais o muro seja negro e o buraco seja branco, os contornos e os olhos se multipliquem são possíveis, pois não se trata de assemelhar-se a um rosto e sim de organizar o traços de rostidade que assumem o papel de sobrecodificação para as partes decodificadas, ou seja, o trabalho da máquina abstrata. Neste caso, não seria somente o visus (Canevacci, 1998) em primeiro plano que lhe concederia a condição de máscara da modernidade, mas toda uma série de recursos técnicos e estéticos seriam mobilizados a fim de autenticar aquilo é qualidade do propriamente televisivo.

Tais molduras e moldurações acionadas pela produção televisiva confeririam às unidades discretas seus sentidos identitários, construtos televisivos que, para Kilpp (2003), são as "ethicidades televisivas". Tais subjetividades virtuais só se parecem com as coisas de outros domínios, mas elas se atualizam, de fato, apenas no mundo televisivo. Cada gênero, cada programa e cada canal agencia seus sentidos por emolduramentos próprios da produção televisiva que, embora perceptíveis na tela pelo processo analítico, tornam-se opacos aos olhos dos espectadores habituados, que se fixam ao teor conteudístico dos programas ou, nos termos de Bergson (1999), prendem a atenção no que é necessário para agir no presente.

A comunicação dos sentidos, portanto, é agenciada entre emissor e receptor (que compartilham, mesmo que minimamente, um imaginário tecnocultural comum (KILPP, 2010). Uma das principais molduras é, inclusive, a do corpo do espectador (dotado de um repertório individual que evoca certas imagens-lembrança). A partir disto, propõe-se que, nesta comunicação, mais uma vez, o trabalho da máquina abstrata atua sobre o universo televisual através de contornos rosticizantes que lhe são próprios. No caso do estudo sobre aspectos da televisão brasileira, o papel que cada rosto assume fica muito evidente ao comparar-se emissoras diferentes ou mesmo programas diferentes em um mesmo canal. 
Toma-se, assim, dois programas telejornalísticos de canais distintos como materiais de análise, os telejornais SBT Brasil, do canal de TV aberta SBT, e Estúdio i, do canal de TV a cabo GloboNews. O SBT Brasil é produzido e exibido ao vivo e vai ao ar de segunda a sábado das $19 \mathrm{~h} 50$ às 20h30, sendo o principal telejornal da emissora. Estreou em 15 de agosto de 2005, com a apresentação da jornalista Ana Paula Padrão. No momento da elaboração deste estudo, é apresentado por Joseval Peixoto e Rachel Sheherazade.

O Estúdio i é considerado um programa jornalístico que mescla entrevistas, comentários e debates em uma atmosfera informal de apresentação da informação. É exibido no canal de TV a cabo GloboNews, de segunda a sexta-feira, das $14 \mathrm{~h}$ às $16 \mathrm{~h}$, com eventuais sínteses da semana aos sábados. Também é exibido pela TV Globo Parabólica e TV Globo Internacional para 157 países. O programa, que estreou em 27 de outubro de 2008, é apresentado por Maria Beltrão, e conta com a participação de um time de 12 comentaristas, especializados em diferentes assuntos, que se revezam diariamente, ao vivo.

Vejamos o caso do programa Estúdio i (Figura 1). Já de início, percebe-se que há várias molduras (Kilpp, 2003) que agem como filtros. Além da logomarca da emissora que autentica a todo o tempo as imagens, enunciando que aquele é um produto com o padrão GloboNews, há ainda a logomarca específica do Estúdio i no lado superior esquerdo, ou seja, evidencia-se que o programa busca se diferenciar, já que outros programas do mesmo canal não adotam tal moldura. Ainda como filtro, destaca-se na parte inferior da tela, uma uma espécie de box que contém legendas que trazem informações sempre dinâmicas, muito semelhante às adotadas por canais de notícias internacionais, deixando claro que o modelo do rosto dominante a ser seguido pelo GloboNews faz referência a esta estética.

Figura 1 - Fotos da tela, capturadas ao vivo em diferentes momentos do programa Estúdio I do dia 28 de junho de 2016.
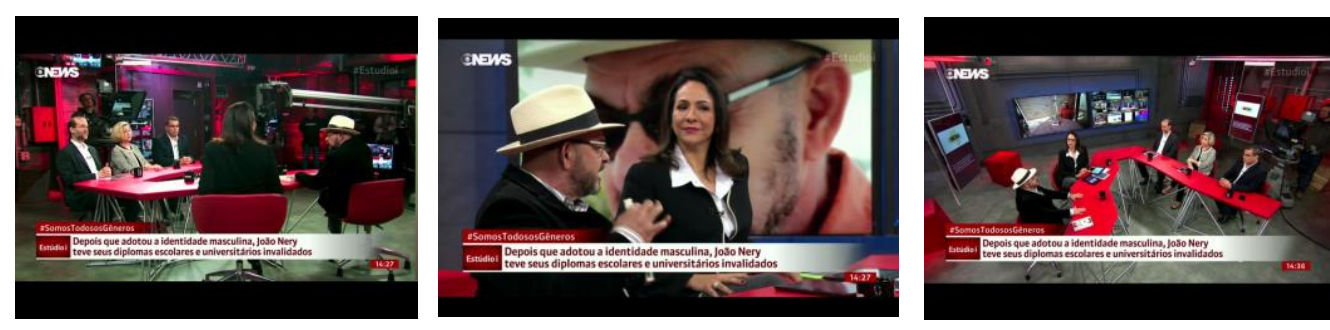

Fonte: Captura de telas pelo autor.

Em relação às imagens que representam o cenário, várias molduras pouco frequentes neste gênero podem ser constatadas. A começar pelo layout do cenário, que foi customizado no estilo industrial. Eletrodutos aparentes, paredes que se assemelham ao concreto, piso de cimento 
PROGRAMA DE PÓS-GRADUAÇÃO EM COMUNICAÇÃO DA UNIVERSIDADE FEDERAL DE SANTA MARIA

queimado, equipamentos de emergência à mostra, setores técnicos, profissionais e equipamentos escancarados à vista do telespectador. Evidentemente, as moldurações aí praticadas buscam construir sentidos identitários que remetam a um ambiente despojado, informal, que visa a um maior envolvimento do público com a equipe e a forma de produção do programa. Tão importante é a aposta nestas molduras para reforçar uma autenticidade da atração que a chamada para o programa, exibida nos breaks, consiste em uma animação em 3D da planta baixa do estúdio.

Algumas das molduras que mais chamam a atenção, neste cenário do Estúdio i, são a bancada, os movimentos de câmera, ângulos de tomada e a composição das imagens. A bancada foi concebida ao estilo minimalista com um tampo vermelho seguindo um formato irregular, que coloca a apresentadora, os comentaristas e os entrevistados todos no mesmo nível e de frente uns para os outros, construindo um sentido identitário de pluralismo. No entanto, são os suportes metálicos delgados da bancada que mais surpreendem ao deixar as pernas e pés dos participantes todos à mostra, imagem inusitada para programas de jornalismo na televisão brasileira. Ao longo do programa, percebe-se um inflacionamento dos movimentos de câmera e ângulos de tomada, passando a sensação de dinamismo imagético ao espectador. A composição das imagens é a maior inovação se comparado com o que se costuma ver em telejornais. Dentre as formas montagem das imagens, a filmagem por detrás da bancada, mostrando os outros operadores de câmera, os produtores e o teleprompter sendo lido pela apresentadora, configuram uma molduração que remete a sentidos de experimentalismo televisual.

De todas as molduras, contudo, as que mais consolidam os traços rosticizantes do programa talvez sejam aquelas que são praticadas no corpo da apresentadora. Maria Beltrão é a cara do Estúdio i. Despachada, bem humorada, inteligente, cordial e simpática são alguns dos sentidos enunciados a partir da sua figura, uma verdadeira "ethicidade televisiva" (Kilpp, 2003). Sua imagem é tão importante para a composição da cara do programa que ela é a própria vinheta do Estúdio i. Nesta perspectiva, a imagem de Maria Beltrão pode ser considerada o rosto do Estúdio I, imagem síntese de tudo aquilo que o programa quer representar para o público. "Despachada", "bem humorada", "inteligente", "cordial" e "carismática" são alguns dos sentidos enunciados a partir desta subjetividade virtual. Sua figura compõe a singularidade do programa como sua principal imagem-rosto, perfazendo boa parte da vinheta do Estúdio I, exibida nas chamadas durante toda a programação do canal. Note-se que, ao se referir à Maria Beltrão, esta-se falando de uma imagem televisa e não da pessoa física que 
encarna este personagem. Sua forma de atuação na tela corresponde à montagem de um dispositivo mais amplo do qual participam outras imagens-rosto, dos quais participam outras ethicidades, como os comentaristas, os convidados, os entrevistados e até mesmo os produtores, técnicos e cenários que são moldurados na tela.

O SBT Brasil (Figura 2), por sua vez, apresenta outra imagem-rosto, que configura o padrão nos telejornais brasileiros desta faixa de horário. Claro que há peculiaridades, mas o rosto-modelo a ser copiado aqui é do Jornal Nacional da Rede Globo. É neste sentido que as molduras-filtros na tela se resumem à logomarca da emissora e a algumas legendas no momento em que aparecem os âncoras, nada diferente do que temos visto há décadas dentro das modulações propostas pelo telejornalismo. Certamente que os sentidos desta economia visual ascética estão ligados à ideia de sobriedade e confiabilidade. As molduras vistas no estúdio seguem um padrão de bancada tradicional, com uma mesa fechada e dois âncoras (um homem e uma mulher), com destaque para alguns elementos que remetem a um design visual moderno, com materiais que suscitam sentidos relacionados aos avanços tecnológicos, em que todas superfícies brilham sem cessar e a iluminação principal é reforçada por inúmeros pontos de iluminação indireta feita por detrás de painéis e até mesmo vindas debaixo do piso semitransparente. Como clichê, se observa uma tela atrás da bancada na qual permanece um mapa do Brasil no centro do mundo, reiteradamente substituído por imagens das matérias

Figura 2 - Fotos da tela, capturada ao vivo em diferentes momentos do programa SBT Brasil do dia 14 de julho de 2016.
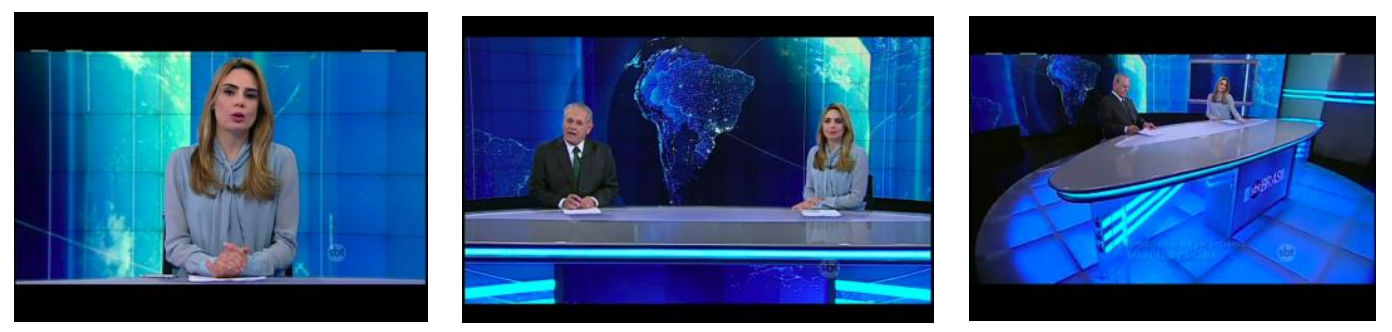

apresentadas durante o telejornal.

Fonte: Captura de telas pelo autor.

Os movimentos de câmera, as tomadas e a composição seguem um ciclo cadenciado que se repete como relógio bem ajustado. São mostrados os jornalistas na bancada em plano mais aberto, alternando com planos médios, conforme cada notícia é anunciada e, novamente, 
retornando ao plano mais aberto do estúdio. A maior ousadia é observada na abertura dos blocos quando um travelling de cima para baixo em 45 graus vai se aproximando dos âncoras. Até mesmo a moldura figurino e a forma dos apresentadores lerem as notícias no teleprompter, no SBT Brasil, é praticada com vistas a sentidos identitários relacionados ao conservadorismo televisual e à busca por uma imagem mais sisuda relacionada à ideia, já bastante questionada, de imparcialidade jornalística.

Neste programa, o elemento rosticizante mais expressivo se estabelece pelo eixo do imaginário tecnocultural. Nem mesmo a ethicidade Sheherazade, com sua postura moralista e discursos populistas inflamados, poderá substituir a lembrança da imagem daquele que é o rosto-mor do SBT: Sílvio Santos. No máximo, os âncoras do jornal fazem a substituição daquela estética meio brega, meio cômica, por vezes reacionária (nem por isto menos afectiva e influente para gerações de brasileiros), que moldura sentidos que remetem ao sensacionalismo, ao fait divers. Note-se que não se está falando do conteúdo do programa, do teor das notícias, mas das molduras que, em conjunto, constroem um rosto que é próprio do programa, das imagens que, montadas de uma certa maneira, dão a ver a forma de se enunciar ao seu público.

Não obstante o SBT Brasil ser um telejornal que remeta ao hard news, as molduras e modurações praticadas oferecem ao espectador sentidos deveras diversos. Chama atenção, portanto, não a demonstração das dessemelhanças entre estilos jornalísticos ou entre as emissoras de televisão ou de como o conteúdo de cada jornal reflete suas filiações editoriais. Mas as dissecações através da metodologia das molduras evidenciam como estes sentidos são consubstanciados a partir de elementos imagéticos discretos, técnicos e estéticos, e como estes sentidos são emoldurados pela produção de cada telejornalístico de forma distinta, o que muitas vezes não têm sido objeto de estudo dentro do campo da comunicação. Tais contingenciamentos praticados pelas instâncias produtivas podem ser comunicados e compreendidos como traços de uma rosticidade televisual abrangente, que se atualiza em rostos, marcas de um imaginário tecnocultural (razão compartilhada, significação social, memória) sendo percebido pela moldura-corpo do telespectador (afectos, subjetivação, lembrança).

\section{PROPOSIÇÕES FINAIS}

Através do processo de dissecação de molduras (técnicas e estéticas), buscamos mostrar os elementos que geralmente permanecem opacos no fluxo comunicacional no qual se realiza 
o consumo de televisão, nos programas telejornalísticos Estúdio i e SBT Brasil. As molduras autenticadas fazem parte de um sistema maior de montagem e oferta de sentidos (moldurações e emolduramentos) - agenciados pela instância produtora e percebidos assimetricamente pelos espectadores - os quais encontram nas imagens as atualizações daquilo que denominamos traços de rosticidade. Pode-se considerar que estes traços são atualizações de ethicidades, uma vez que existem enquanto tais apenas como construções televisivas.

Fica patente que opera, nos programas analisados, uma máquina abstrata de rostidade, haja vista a potência dos meios na constituição política de rostos e na manutenção de modelos rostizantes. A constituição de uma imagem-rosto para os programas só passa no crivo da máquina quando indexada à noção de que, de alguma forma, o rosto pode ser engolido para ser aceito. O conjunto de molduras destacadas de sua opacidade habitual dão a ver o trabalho da ação das duas funcões do dispositivo maquínico: a das unidades e a das escolhas. A primeira funciona como um terceiro olho que esquadrinha o espaço procurando na superfície do muro, qualquer que seja seu conteúdo, uma unidade de rosto aceitável segundo seu sistema geral de referência. Tal rosto deverá ter uma relação biunívoca com seu oposto: "é inovador ou conservador, é descontraído ou sério, é sofisticado ou cafona, é moderno ou antigo, é amigo ou inimigo". A outra função é complementar e opera por seleções do tipo "sim" ou "não", aceita ou não aceita, em cada situação, de acordo com seus critérios despóticos. No entanto, se nos outros domínios, o homem só terá uma possibilidade de vida se buscar escapar do rosto e desarmar a máquina, como propõem Deleuze e Guattari (1996), no mundo televisivo, esta lógica parece se inverter: não ter rosto talvez signifique o "fora do ar".

Não é, portanto, a individualidade de um rosto que desencadeia a máquina, mas certos agenciamentos de poder têm a necessidade de produzir rostos eficazes. "Não é questão de ideologia, mas de economia e de organização do poder (DELEUZE \& GUATTARI, 1996, p. 42)". Os autores dão exemplos comuns: o poder do cinema que passa pelo close, o poder passional que passa pelo rosto do amado, o poder materno que passa pelo rosto da mãe na amamentação, etc. Neste sentido, não é de se espantar que o poder da televisão passe pela imagem dos apresentadores e demais elementos visuais. Os acontecimentos jornalísticos, as narrativas desterritorializadas, reterritorializam-se na superfície da tela, cifrados de um outro modo pela imagem das ethicidades televisivas telejornalísticas.

Os conjuntos de imagens analisadas mostram molduras construídas em perspectiva albertiana, cuidadosamente enquadradas e compostas de forma a permitir que sejam encaixadas as demais molduras e moldurações. Pode-se considerar que tais elementos têm uma função 
estética importante na formação das imagens-rosto dos programas. Os elementos imagéticos, os personagens, os apresentadores, etc., assim como a própria forma da tela, cujas bordas são limitadas pelo aparelho no qual se assiste a transmissão, constituem-se como superfície de significação, tela vazia a ser preenchida por outras molduras, espaço sobre o qual são moldurados os logos, os cenários, os enquadramentos, os movimentos de câmera, sendo ela mesma, a tela, uma moldura, culturalmente aceita e compartilhada, a englobar as demais.

Até mesmo o design do conjunto é produzido para fazer "caber" na tela da televisão um conjunto de signos com vistas a enunciar certos significados. "A rostificação não opera por semelhança, mas por ordens de razão (DELEUZE \& GUATTARI, 1996, p. 35)”. São as próprias coisas que se rostificam, passam de outros estratos para o de significância e subjetivação. A tela é enquadrada necessariamente para deixar espaço às demais molduras, "os olhos se distribuem". Os buracos negros distribuem-se com seus olhos multiplicados na superfície do muro. Não como unidade, mas como margens que encerram em seus buracos cada vez mais olhos. O efeito deste aumento é um rosto que atua pela proliferação de redundâncias. Os buracos não competem, se complementam. A composição de tais molduras pode mesmo configurar o mapa da montagem das imagens televisivas. "O rosto é uma superfície: traços, linhas, rugas do rosto, rosto comprido, quadrado, triangular; o rosto é um mapa, mesmo se aplicado sobre um volume, envolvendo-o, mesmo se cercando e margeando cavidades que não existem mais senão como buracos (DELEUZE \& GUATTARI, 1996, p. 35)”.

Desta forma, com o conceito de rosticidade, a ideia de um dispositivo que torna rosto aquilo que não é rosto, em uma "máquina abstrata", evidencia-se que há um devir-rosto, uma qualidade comunicacional, uma potência de devir-rosto pronta para se atualizar, sempre diferindo de si, nas materialidades televisuais analisadas. Por outras palavras, a rosticidade de um programa, de um canal ou da televisão brasileira, seja dos canais “abertos" ou "pagos”, se atualiza como a cara do SBT Brasil ou a cara do Estúdio i através das molduras e moldurações de ethicidades televisivas, das quais foram dissecados neste artigos apenas alguns fragmentos de um universo possível de molduras sobrepostas que agem em múltiplos domínios, como o cultural, o econômico, o político, o técnico, etc. Quando concretiza sua fisionomia em conjuntos de materialidades, atualiza e fixa um instante da transformação de seu rosto no tempo, produzidas e mediadas tecnicamente. A rosticidade de um determinado dispositivo midiático é capaz de mobilizar perceptos e afectos compartilhados coletivamente através de imaginários tecnoculturais e, individualmente, através de imagens-lembrança. 


\section{REFERÊNCIAS BIBLIOGRÁFICAS}

APPADURAI, Arjun. Modernity at large: cultural dimensions of globalization. Minneapolis: University of Minnesota Press, 1996.

BALÁZS, Bel. A face das coisas. In: XAVIER, Ismail (org.). A Experiência do Cinema. Rio de Janeiro: Graal, 2003.

BALTRUSAITIS, Jurgis. Aberrações: ensaio sobre a lenda das formas. Rio de Janeiro: UFRJ, 1999.

BENJAMIN, Walter. A obra de arte na era de sua reprodutibilidade técnica. In: BENJAMIN, Walter. Mágia e técnica, arte e política: ensaios sobre literatura e história da cultura. São Paulo: Brasiliense, 1989.

. Pequena história da fotografia. In: BENJAMIN, Walter. Mágia e técnica, arte e política: ensaios sobre literatura e história da cultura. São Paulo: Brasiliense, 1989.

BERGSON, Henri. Matéria e memória. 2. ed. São Paulo: Martins Fontes, 1999.

O pensamento e o movente. São Paulo: Martins Fontes, 2006.

CANEVACCI, Massimo. Antropologia da comunicação visual. São Paulo: Brasiliense, 1998.

CASTORIADIS, Cornélius. A instituição imaginária da sociedade. Rio de Janeiro: Paz e Terra, 1982.

DELEUZE, Gilles; GUATTARI, Félix. Mil Platôs: Capitalismo e esquizofrenia Vol. 3. Rio de Janeiro: Ed. 34, 1996.

DELEUZE, Gilles. Bergsonismo. São Paulo: Editora 34, 2004.

A imagem-movimento: Cinema 1. São Paulo: Martins Fontes, 2009.

ECO, Umberto. Sobre os espelhos e outros ensaios. Rio de Janeiro: Editora Nova Fronteira, 1989.

GOMES, Marcelo Salcedo. A Rosticidade da Tecnocultura na Galáxia National

Geographic. Tese de doutorado. Universidade do Vale do Rio dos Sinos, São Leopoldo, 286 p., 2017.

FLICHY, Patrice. La place de I’imaginaire dans I’action technique: Le cas de l'internet. Réseaux, v.5, n. 109, p. 52-73, 2001.

FROSH, Peter. The Face of Television. The ANNALS of the American Academy of Political and Social Science, n. 625, p. 87-102, 2009.

KILPP, Suzana. Ethicidades televisivas. Sentidos identitários na TV: moldurações homológicas e tensionamentos. São Leopoldo: Editora Unisinos, 2003. 
KILPP, Suzana. A traição das imagens. Porto Alegre: Entremeios, 2010.

Dispersão-convergência: apontamentos para a pesquisa de audiovisualidades. In: MONTAÑO, Sonia; FISCHER, Gustavo e KILPP, Suzana (Orgs.). Impacto das novas mídias no estatuto da imagem. Porto Alegre: Sulina, 2011.

Como ver o que nos olha. In: KILPP, Suzana; FISCHER, Gustavo Daudt (Orgs.). Para entender as imagens: como ver o que nos olha? Porto Alegre: Entremeios, 2013.

LAGE, Leandro Rodrigues. O rosto do sofrimento na TV: notas sobre o primeiro plano no telejornalismo, Animus, v.16, n.31, p. 159-177, 2017.

MARQUES, Angela Cristina Salgueiro; BIONDI, Angie. Omayra: reflexões sobre o rosto, uma fotografia e suas políticas. Galáxia (São Paulo), São Paulo, n. 33, p. 145-157, Dez, 2016.

PICADO, Benjamin. A ação e a paixão que se colhem num rosto: pensando os regimes de discurso do retrato humano no fotojornalismo. Galáxia (PUCSP), v. 18, p. 284-299, 2009.

TAYLOR, Charles. Modern social imaginaries. London e Durhan: Duke University Press,2004.

Original recebido em: 15 de agosto de 2016

Aceito para publicação em: 19 de setembro de 2019

Marcelo Salcedo Gomes

Psicólogo e jornalista, Mestre e Doutor em Ciências da Comunicação pela UNISINOS, Marcelo Salcedo Gomes tem realizado investigações nas linhas de pesquisa Mídias e Processos Audiovisuais e Midiatização e Processos Sociais. No campo da Comunicação, tem experiência nas áreas de fotojornalismo, fotodocumentarismo, teorias da comunicação, semiótica, midiatização, fotografia publicitária e ensino de fotografia. No campo da Psicologia, tem experiência em orientação profissional e processos de aprendizagem.

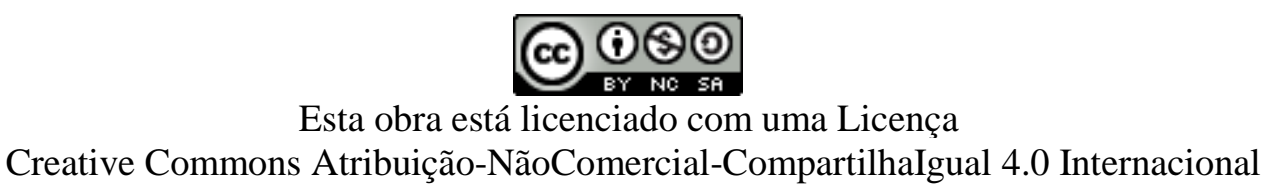

